Костюрина Н. Ю.

N. Yu. Kosturina

РЕЦЕНЗИЯ НА КНИГУ И. И. ДОКУЧАЕВА «ЭДМУНД ГУССЕРЛЬ». САНКТ-ПЕТЕРБУРГ: НАУКА, 2017. - 288 С. - (МЫСЛИТЕЛИ ПРОШЛОГО)

\title{
REVIEW OF I. I. DOKUCHAEV'S BOOK «EDMUND HUSSERL». - ST. PETERSBURG: SCIENCE, 2017. - 288 P. - (THINKERS OF THE PAST)
}

Костюрина Надежда Юрьевна - доктор культурологии, профессор кафедры философии и культурологии Комсомольского-на-Амуре государственного университета (Россия, Комсомольск-на-Амуре). E-mail: kosturina@mail.ru.

Ms. Nadezhda Yu. Kostyurina - Doctor in Cultural Studies, Professor, Department of Philosophy and Cultural Studies, Komsomolsk-on-Amur State University (Russia, Komsomolsk-on-Amur). E-mail: kosturina@mail.ru.

Новая книга профессора И. И. Докучаева вышла в научно-популярной серии «Мыслители прошлого», возобновленной издательством «Наука» после большого перерыва. Старая серия началась с публикации издательством «Соцэкгиз» в 1963 году двух книг, посвященных Гердеру и Эпикуру, затем с 1965 по 1994 год в издательстве «Мысль» было опубликовано еще 83 книги, причем с 1991 по 1993 год не вышло ни одной. В новой серии в 2016 и 2017 году было опубликовано еще 16 книг. Каждая книга представляет собой стереотипную структуру, состоящую из пяти частей: биография, основные идеи мыслителя, цитаты из ключевых работ, именной указатель и библиография.

Эдмунд Гуссерль вошёл в историю философии и науки не в качестве очередного создателя философской системы. Надо полагать, что к этому он и не стремился, вопреки традиции. Однако ему удалось то, что удавалось немногим философам. Он создал метод, с помощью которого исследовал ряд традиционных философских и психологических предметов, показав эффективность и продуктивность такого рода работы. Значение этого метода можно оценить, представив себе объем тех предметов, которые оказываются доступны исследованию благодаря ему. Речь идет о целой реальности, которую принято со времён Рене Декарта называть субъективной и противопоставлять объективной реальности. В XX веке стали метафорически называть субъективную реальность речью о бытии от первого лица, а объективную реальность - речью о бытии от третьего лица. Особенностью субъективной реальности является ее непосредственный и очевидный характер. Иначе говоря, она открыта своему исследователю не в ходе каких-то теоретических допущений, а благодаря тому, что сам исследователь и его предмет тождественны, и это тождество есть тождество сознания. Феноменология есть наука о непосредственных данных сознания, и как таковая она включает усмотрение сущностей, или априорных форм сознания, посредством которых открывается какое-либо случайное содержание, а также усмотрение фактичности переживания этих форм. В первом случае феноменология есть априорное, или философское, познание, а во втором - интроспективная психология.

Интерес к проблеме сознания сегодня в первую очередь связан с работами, выполняемыми на стыке биологии, информатики, физики наномира и когнитивной психологии (нанобиоинфокогнонаука, или NBIC). Аналитическая философия стремится синтезировать данные этих наук и представить на основе этого синтеза непротиворечивую логическую модель сознания. Однако такого рода исследование ведется от третьего лица, лишь изредка затрагивая проблемы непосредственной данности сознания самому сознанию в априорных формах и в актах трансцендентальных переживаний. Иначе говоря, структура сознания описывается не на основании того, что известно о сознании непосредственно и очевидно, но на основании косвенных данных о нем. Показательно, что в огромном списке литературы, прилагающемся к тексту философского бестселлера Дэвида Чалмерса «Сознающий ум», нет ни одного упоминания ни об Эдмунде Гуссерле, ни о каком-либо 
Костюрина Н. Ю.

РЕЦЕНЗИЯ НА КНИГУ И. И. ДОКУЧАЕВА «ЭДМУНД ГУССЕРЛЬ». - САНКТ-ПЕТЕРБУРГ: НАУКА,

2017. - 288 С. - (МЫСЛИТЕЛИ ПРОШЛОГО)

другом представителе феноменологического движения [10]. Между тем, невозможно адекватно описывать сознание, не обращаясь к феноменологическим данным о нем. Такое сознание будет представлять собой лишь конструкцию, степень реальности которой всегда будет являться проблемой и дополнительной трудностью для разрешения психофизического вопроса, рассматриваемого в NBIC-перспективе. Феноменологически эксплицированное содержание сознания должно быть положено в основу всех NBIC-описаний психофизического отношения. В противном случае чалмерсовский дуализм субъективного и объективного мира никогда не будет преодолен. Если речь идет об объяснении сознания как функции физических систем, необходимо понять, что именно объясняется, и феноменологическое содержание сознания является как раз тем самым исходным материалом для подобного объяснения, ибо обойти это содержание не представляется возможным.

Концепция Эдмунда Гуссерля представляет собой динамически разворачивающийся текст, в котором нет готовых результатов. Сознание не есть данность такого рода, что ее можно положить как готовый факт и исследовать его свойства. В процессе описания сознания оно не только открывается, но и конструируется, и конструирование это не может быть однажды завершено, оно всегда будет находиться в состоянии генезиса. Сам философский путь Эдмунда Гуссерля - великолепная иллюстрация этого генезиса. Начав с психологических исследований априорных форм сознания, Э. Гуссерль затем открыл несводимость эйдетики к случайному потоку переживаний и стал призывать обратиться к самим вещам, их существенным свойствам, априорным и не зависящим от тех или иных материальных или психических, объективных или субъективных характеристик и аспектов содержания. Однако, обратившись к этим самым эйдетическим, метафизическим свойствам «вещей самих по себе», Эдмунд Гуссерль усмотрел во всем этом слое смыслов вещи не что иное, как свойства самого сознания, его структуру, связанную с ключевыми характеристиками его функционирования. А затем, в заключительный период своей работы, Эдмунд Гуссерль обнаружил еще одну существенную особенность этих форм - их генетический и антиномический характер. Априорное и метафизическое подверглось генетической переработке, включилось в исторический ряд становления.

В книге-эссе И. И. Докучаева представлена персональная и духовная биография Эдмунда Гуссерля. Рассказ о жизни Эдмунда Гуссерля (первая часть эссе) представлен традиционно: от рождения до кончины (здесь же описана история взаимоотношений Э. Гуссерля и его феноменологии с математическими и философскими традициями XIX и XX веков, которые были близки ей: неокантианцы, школа Ф. Брентано, мюнхенские феноменологи Т. Липпса, геттингенские феноменологи, фрайбургские феноменологи, феноменологическое движение после Э. Гуссерля), а вот духовная биография (вторая часть эссе) традиционно развернута как история текстов и идей лишь в одной - первой главе второй части эссе; а затем, в каждой из последующих пяти глав представлены ключевые принципы феноменологии, сначала в том виде, в каком они были предложены Эдмундом Гуссерлем, а затем в том виде, в каком они могут быть обоснованы сегодня в качестве ключевых инструментов философского метода. Речь идет о месте феноменологии в истории философии с точки зрения решения вопроса о бытии и истине, о фундаментальных процедурах феноменологии (редукциях), интенциональности и ноэтико-ноэматической корреляции (вторая глава), о статической феноменологии (о времени и эгологии, о пространстве и вещи, об интерсубъективности) (третья глава), о генетической феноменологии (о жизненном мире, ценностях и истории) (четвертая глава), об итогах феноменологического проекта (монистических задачах и антиномических возможностях феноменологической дескрипции) (пятая глава). Значение Эдмунда Гуссерля для философии в целом и для философии XX века в частности трудно переоценить. Оно вполне сопоставимо со значением Аристотеля и Платона для античной эпохи, Фомы Аквинского и Дунса Скотта для средневековья, Рене Декарта, Бенедикта Спинозы и Вильгельма Лейбница - для эпохи Классицизма и барокко, Иммануила Канта, Иоганна Фихте и Георга Гегеля для эпохи Просвещения и позитивизма. Поэтому центральную часть эссе можно назвать, воспользовавшись восходящим к Декарту и Гуссерлю стилистическим аналогом, предложенным Робертом Соколовски, Гуссерлианские размышления. 


\section{Учёные записки}

Комсомольского-на-Амуре государственного технического университета

В конце книги (третья часть) помещаются выдержки из ключевых работ Эдмунда Гуссерля (в примечаниях указаны выходные издания книг на русском и немецком языках, из которых приводятся цитаты; почти все ключевые работы Эдмунда Гуссерля сегодня переведены на русский язык, однако досадное исключение из этого правила составляет вторая часть второго тома «Логических исследований», а также «Формальная и трансцендентальная логика»): «Логические исследования» $[2 ; 7 ; 8]$, «Феноменология внутреннего сознания времени» [9], «Философия как строгая наука» [4], «Идеи к чистой феноменологии и феноменологической философии» [3], «Формальная и трансцендентальная логика» [1], «Картезианские размышления» [5], «Кризис европейских наук и трансцендентальная феноменология» [6]. В целом, эссе посвящено только феноменологии Эдмунда Гуссерля, поэтому ряд феноменологических тем, таких как феноменология социальных коммуникаций или эстетическая феноменология, развивавшихся параллельно с исследованиями Гуссерля и после его кончины Альфредом Шюцом, Романом Ингарденом и другими выдающимися феноменологами, а также другие темы и концепции не затрагиваются в рецензируемой работе.

Книга И. И. Докучаева - не вполне научно-популярный труд, но в этом сложно найти недостаток, поскольку философия Э. Гуссерля слишком сложна и плохо поддается популяризации. Заслуга книги в том, что концепция основоположника феноменологии представлена целостно и в развитии. Акцент сделан на ключевые и наиболее проблемные темы феноменологии. Показаны перспективы феноменологии и философии в целом в наше непростое время критики философии как научного проекта. Книга будет чрезвычайно полезна как профессионалам философам, так и широкому читателю, который интересуется судьбой философии сегодня и ее основными результатами в XX веке.

\section{ЛИТЕРАТУРА}

1. Husserl, E. Formale und transzendentale Logik: Versuch einer Kritik der logischen Vernunft / E. Husserl. - Berlin: De Gruyter, 1981. - 309 s.

2. Husserl, E. Logische Untersuchungen. Band 2. Untersuchungen zur Phänomenologie und Theorie der Erkenntnis. Teil 2. Elemente einer phänomenologischen Aufklärung der Erkenntnis / E. Husserl. - Tübingen: Max Niemeyer Verlag, 1968. - $244 \mathrm{~s}$.

3. Гуссерль, Э. Идеи к чистой феноменологии и феноменологической философии. Т. 1. Общее введение в чистую феноменологию / Э. Гуссерль. - М.: Академический проект, 1999. - 489 с.

4. Гуссерль, Э. Избранные работы / Э. Гуссерль. - М.: Издательский дом «Территория будущего», 2005. 464 c. $($ C. $185-241)$

5. Гуссерль, Э. Картезианские размышления / Э. Гуссерль. - СПб.: Наука, 1998. - 315 с.

6. Гуссерль, Э. Кризис европейских наук и трансцендентальная феноменология: Введение в феноменологическую философию / Э. Гуссерль. - СПб.: Владимир Даль, 2004. - 398 с.

7. Гуссерль, Э. Логические исследования. Том І. Пролегомены к чистой логике / Э. Гуссерль. - М.: Академический проект, 2011. - 256 с.

8. Гуссерль, Э. Собрание сочинений. Т. 3 (1). Логические исследования. Т. ІІ (1). Исследования по феноменологии и теории познания / Э. Гуссерль. - М.: Гнозис, Дом интеллектуальной книги, 2001. - 584 с.

9. Гуссерль, Э. Собрание сочинений. Том І. Феноменология внутреннего сознания времени / Э. Гуссерль. М.: «Гнозис», РИГ «ЛОГОС», 1994. - 177 с.

10. Чалмерс, Д. Сознающий ум: В поисках фундаментальной теории / Д. Чалмерс. - M.: URSS, 2015. - 512 с. 